\title{
What Next for Minimally Invasive Glaucoma Surgery (MIGS)?
}

\author{
Ejaz Ansari* \\ Canterbury Christchurch University, UK
}

Submission: October 26, 2017; Published: November 20, 2017

*Corresponding author: Ejaz Ansari, Maidstone \& Tunbridge Wells NHS Trust, Kent, Institute of Medical Sciences, Canterbury Christchurch University, Kent, UK, Tel: +1622 226275; Email: e.ansari@nhs.net

\section{Introduction}

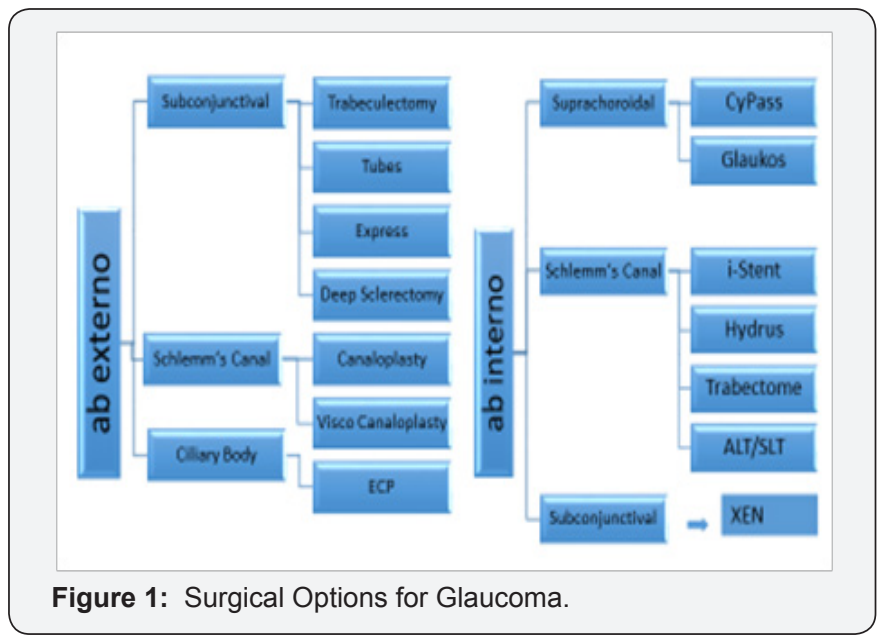

In their quest for safer surgery and better outcomes for their patients, glaucoma surgeons in many parts of the world have increasingly embraced minimally invasive glaucoma surgery (MIGS) procedures. Although generally safer than established surgical techniques, they remain a relatively new approach and the long-term benefits for patients and cost-effectiveness are unknown. MIGS describes a broad range of procedures which could be ab interno or ab externo, either with or without the use of implants (Figure 1). Most of the recent focus in the literature has been on MIGS implants, which can achieve the aim of intraocular pressure (IOP) reduction by one of three means: accessing the Schlemm's canal (SC) and collector channels; through the suprachoroidal space and the familiar subconjunctival space. In practical terms, IOP remains the only modifiable risk factor in glaucoma treatment.

Although some implants, particularly the subconjunctival ones, have been employed in tackling cases of advanced glaucoma, MIGS procedures generally, are positioned between medication and trabeculectomy in the treatment paradigm. Usually, they offer a modest reduction in IOP and medications post-operatively, and are predicated on being tissue sparing, safer and quicker both for the surgeon and the patient, with speedier visual rehabilitation. There are many MIGS publications, but few randomised controlled trials (RCTs), a lack of standardisation in study design and few standalone (i.e. without concomitant cataract surgery) studies. However, some interesting observations on efficacy and safety can be drawn from the current literature, with emphasis on the RCTs and comparative studies that are available.

Trabecular meshwork bypass stents, include iStent (Glaukos Corp., Laguna Hills, CA, USA), which has been in use for several years and is FDA approved. Since most MIGS procedures are combined with cataract extraction and lens implant (CE+IOL), it is difficult to elucidate the effect of the implant alone. Therefore, studies comparing combined procedures with $\mathrm{CE}+\mathrm{IOL}$ are important. One RCT showed a significant reduction in IOP and medications compared to cataract surgery alone [1]. There is evidence that potentially accessing multiple collector channels with more than one iStent is more efficacious in IOP reduction [2]. This has spawned the development of a second generation iStent, the iStent Inject/ model GST400 (Glaukos Corp., Laguna Hills, CA, USA), which is pre-loaded with 2 stents. Favourable reductions in IOP and medications were demonstrated in standalone studies, with follow-up of 12 and 18 months [3,4] and in a 4 year combined study [5]. These studies were nonrandomised and non- comparative.

Hydrus (Ivantis Inc, Irvine, CA, USA)- is another trabecular meshwork bypass stent that straddles 3 clock hours of SC, with the aim of accessing more collector channels and dilating the SC, acting as a scaffold so that it does not block the collector channel ostia.

A RCT of 100 cases randomised to cataract surgery alone or combined cataract surgery with Hydrus, has been completed [6]. At 24 months, a significantly greater proportion of combined surgery cases reached the endpoint of $20 \%$ reduction in washed out diurnal IOP and the IOP was also significantly lower in the combined surgery group. There was also a significant reduction 
in cases without ocular hypotensive medications in the combined surgery group.

Implants accessing the suprachoroidal space include the CyPass (Alcon, Fort Worth, TX, USA), which is FDA approved and is delivered ab interno, forming a conduit between the anterior chamber and suprachoroidal space. A 24 months RCT of 505 subjects randomized to $\mathrm{CE} / \mathrm{IOL}+\mathrm{CyPass}$ or CE/IOL alone demonstrated fairly similar IOP lowering of $7.4 \mathrm{mmHg}$ compared to $5.4 \mathrm{mmHg}$ in the control group, but the difference being statistically significant $(\mathrm{p}<0.001)$, with $85 \%$ of treated patients drop-free at 24 months [7]. In a 12 month standalone study, CyPass achieved a $35 \%$ reduction in IOP at 12 months with a reasonable reduction in drop dependency [8].

Subconjunctival implants appear to have superior efficacy compared to other devices. However, there is a lack of high quality evidence for this group of implants. The XEN gel stent (Allergan,

Table 1: Summary of efficacy and safety data.

\begin{tabular}{|c|c|c|c|c|c|c|}
\hline & $\begin{array}{c}\text { Phaco/ } \\
\text { iStent (1) }\end{array}$ & $\begin{array}{l}\text { Phaco/iStent } \\
\text { inject (5) }\end{array}$ & $\begin{array}{c}\text { Phaco/ } \\
\text { Hydrus (6) }\end{array}$ & $\begin{array}{c}\text { Phaco/ CyPass } \\
\text { (7) }\end{array}$ & $\begin{array}{c}\text { Phaco/ } \\
\text { XEN } 45 \text { (11) }\end{array}$ & $\begin{array}{c}\text { InnFocus } \\
\text { (12) }\end{array}$ \\
\hline $\begin{array}{l}\text { Pre-op IOP } \\
\text { (mmHg) }\end{array}$ & 18.6 & 26.0 & 26.3 & 24.4 & 16.0 & 23.8 \\
\hline $\begin{array}{l}\text { Post-op IOP } \\
\text { (mmHg) }\end{array}$ & 17.0 & 16.25 & 16.9 & 17.0 & 12.0 & 10.7 \\
\hline $\begin{array}{l}\% \text { IOP drop; } \\
\% \text { medication } \\
\text { reduction }\end{array}$ & $\begin{array}{c}33 \% ; 87 \% \text { (versus } \\
32.5 \% ; 73 \% \text { in } \\
\text { controls) }\end{array}$ & $36.92 \% ; 42 \%$ & $\begin{array}{c}50 \% ; 73 \% \text { (versus } \\
28 \% ; 38 \% \text { in } \\
\text { controls }\end{array}$ & $\begin{array}{c}30.3 \% ; 85.7 \% \\
\text { (versus } 22 \% \\
53.9 \% \text { in controls) }\end{array}$ & & $55 \% ; 69.2 \%$ \\
\hline AEs & $\begin{array}{l}0.85 \% \text { endothelial } \\
\text { touch; } 6 \% \text { iris } \\
\text { touch; } 4.2 \% \\
\text { secondary surgery }\end{array}$ & & $\begin{array}{c}12 \% \text { focal } \\
\text { peripheral } \\
\text { anterior synechiae }\end{array}$ & & $\begin{array}{c}\text { Transient } \\
\text { choroidal } \\
\text { detachment=2, } \\
\text { tube extrusion=1, } \\
\text { trabeculectomy=2 }\end{array}$ & $\begin{array}{c}\text { Transient } \\
\text { hyptony=13\% } \\
\text { transient } \\
\text { choroidal } \\
\text { effusion=8\% }\end{array}$ \\
\hline
\end{tabular}

The Innfocus microshunt (Santen Pharm Ltd, Osaka, Japan) is an ab externo drainage device targeting the subconjunctival space. It involves more steps akin to trabeculectomy compared to other MIGS. Long-term IOP reduction is encouraging with $80 \%$ reaching $\mathrm{IOP}</=14 \mathrm{mmHg}$ at 3 years, some cases being standalone and others combined. The mean IOP for the entire group was $10.7+/-1.5 \mathrm{mmHg}$ at 3 years; qualified success rate was $95 \%$ with a reduction in medications from $2.6+/-0.9$ to $0.8+/-1.2$ [12]. Therefore, subconjunctival procedures appear to be more efficacious (Table 1 ), but inevitably require more post-operative bleb management, and potentially restrict future incisional procedures if required.

MIGS procedures have come a long way but are still evolving. More work is required to evaluate these procedures, particularly with more randomised controlled trials, standalone and comparative studies and cost-effectiveness modelling, before they can find a place in the glaucoma surgery firmament. With time, as the technology evolves further, clinicians will be better informed about the place of MIGS in their practice. Standardisation and improvements in the quality of future MIGS
Dublin, Ireland) is an ab interno gelatine stent that is implanted via a clear corneal incision without conjunctival dissection. Three models have been evaluated with inner diameters of 45 $\mu \mathrm{m}, 63 \mu \mathrm{m}$, and $140 \mu \mathrm{m}$, with the $45 \mu \mathrm{m}$ being the recommended device by the manufacturer. XEN 45 is FDA approved.

Initial studies with the 63 and 140 model, demonstrated favourable IOP lowering with reduced medication burden, but these studies were not randomised nor were they comparative, usually with a mixture of combined and standalone cases $[9,10]$. The IOP reduction with XEN 45 was $25 \%$ in a small 12 month study, with mainly combined cases [11]. The results from the ongoing APEX study (combined procedures, open angle glaucoma, and 2 year follow-up) demonstrated a mean reduction in IOP of $39 \%$ (mean IOP at 2 years of $13.1 \mathrm{mmHg}$ ) with a mean of 0.7 medications. However, the rate of needling significantly exceeded that seen following trabeculectomy. The results will be published later this year. studies will help clinicians to negotiate this ever-expanding area more knowledgably and help them to optimise the selection of the appropriate device for the right patient. With the correct approach to investigating and evaluating new technologies, there is much potential for future generations of MIGS procedures to improve the quality of care for glaucoma patients.

\section{References}

1. Craven ER, Katz LJ, Wells JM, Giamporcaro JE (2012) Cataract surgery with trabecular micro-bypass stent implantation in patients with mild to moderate open angle glaucoma and cataract: Two year follow-up. J Cat Ref Surg 38(8): 1339-1345.

2. Katz LJ, Erb C, Carceller GA, Fea AM, Voskanyan L, et al. (2015) Prospective randomised study of one, two, or three trabecular bypass stents in open angle glaucoma subjects on topical hypotensive medication. Clin Ophthalmol Auckl NZ 9: 2313-2320.

3. Voskanyan L, García-Feijoó J, Belda JI, Fea A, Jünemann A, et al. (2014) Prospective masked evaluation of the iStent inject system for openangle glaucoma: synergy trial. Adv Ther 31(2): 189-201.

4. Lindstrom R, Lewis R, Hornbeak DM, Voskanyan L, Giamporcaro JE, et al. (2016) Outcomes following implantation of two second generation Trabecular Micro-Bypass Stents in Patients with POAG. Adv Therapeutics 33(11): 2082-2090. 
5. Arriola-Villalobos P, Martinez-de-la-Casa JM, Diaz-Valle D, MoralesFernandez L, Fernandez-Perez C, et al. (2016) Glaukos iStent inject ${ }^{\circledR}$ Trabecular Micro-Bypass Implantation Associated with Cataract Surgery in Patients with Coexisting Cataract and Open-Angle Glaucoma or Ocular Hypertension: A Long-Term Study. J Ophthalmol 2016: 1056573.

6. Pfeiffer N, Garcia-Feijoo J, Martinez-de-la-Casa JM, Larrosa JM, Fea A, et al. (2015) A randomized trial of a Schlemm's canal microstent with phacoemulsification for reducing intraocular pressure in open-angle glaucoma. Ophthalmology 122(7): 1283-1293.

7. Vold S, Ahmed II, Craven ER, Mattox C, Stamper R, et al. (2016) Two-Year COMPASS Results: Supraciliary Microstenting with Phacoemulsification in Patients with Open-Angle Glaucoma and Cataracts. Ophthalmology 123(10): 2103-2111.

8. García-Feijoo J, Rau M, Grisanti S, Grisanti S, Höh H, et al. (2015) Supraciliary micro-stent implantation for open-angle glaucoma failing topical therapy: 1-year results of a multicenter study. Am J Ophthalmol 159(6): 1075-1081.

9. Sheybani A, Lenzhofer M, Hohensinn M, et al. (2015) Phacoemulsification combined with a new ab interno gel stentto treat open-angle glaucoma: pilot study. J Cat Ref Surg 41(9): 1905-1909.

10. Sheybani A, Dick B, Ahmed IIK (2016) Early clinical results of a novel ab interno gel stent for the surgical treatment of open-angle glaucoma. J Glaucoma 25(7): e691-e696.

11. Galal A, Bilgic A, Eltanamly R, Osman A (2017) XEN glaucoma implant with mitomycin C 1 year follow-up: result and complications. J Ophthalmol 2017: 5457246.

12. Batlle JF, Fantes F, Riss I, Pinchuk L, Alburquerque R, et al. (2016) Three year follow-up of a novel aqueous humor microshunt. J Glaucoma 25(2): e58-e65.

\section{Your next submission with Juniper Publishers will reach you the below assets}

- Quality Editorial service

- Swift Peer Review

- Reprints availability

- E-prints Service

- Manuscript Podcast for convenient understanding

- Global attainment for your research

- Manuscript accessibility in different formats ( Pdf, E-pub, Full Text, Audio)

- Unceasing customer service

Track the below URL for one-step submission https://juniperpublishers.com/online-submission.php 